特集「第15回大会」

\title{
原著論文
}

\author{
精油芳香の学習への影響と ERPによる検証 \\ 上條 美和子*, 大森 隆司 $* *$ \\ * 相模女子大学, ${ }^{* *}$ 玉川大学
}

\section{Aroma Effect to Learning and ERP verification}

\author{
Miwako KAMIJO* and Takashi OMORI** \\ * Sagami Women's University, 2-1-1 Bunkyo, Minami-ku, Sagamihara-city, Kanagawa 252-0383, Japan \\ ** Tamagawa University, 6-1-1 Tamagawa-gakuen, Machida-city, Tokyo 194-8610, Japan
}

\begin{abstract}
This research aims to verify the influence of EOAE (essential oil aroma environment) through a behavioral and ERP(event related potential) study. By this we hope to undercover the brain activity which assists sense, learning and knowledge of aroma. EFL (English as a foreign language) class was performed with an EOAE blend of rosemary cineole 1,8 and lemon. As a result, the target group which learned under EOAE did not have significant difference in result. The survey followed with an ERP evaluation using an odd ball task to measure the degree of attention. As a result, a possible P3a and MMN (Mismatch negativity) amplitude was found to differ between the target and control group. P3a is a subcomponent of P300 which is an attention related component, and MMN is a component that detects auditory deviance in an even sequence of tones. Two other unknown EOAE components that assist only with EOAE were also found.
\end{abstract}

Keywords : essential oil aroma, learning behavioral study, brain waves

\section{1.はじめに}

芳香療法 (aroma therapy) とは芳香植物由来の精油 (essential oil）を使った, 補完代替医療の一つである.補完代替医療 (complementary and alternative medical treatment)の定義は さまざまであるが，ここでは医学領域において科学的に未検 証あるいは臨床未対応となった医療体系であると定義する。

現状では，アロマセラピスト（aroma therapist）は長い期間 を経て蓄積された知識と経験に基づいて精油の芳香療法を 行っており, 需要も増える傾向が伺える. しかし精油芳香の 学習に対する効果について科学的な根拠が示された例は多く はない，そこで本研究では，1）精油芳香下での学習に対す る効果を行動調査で，2）精油芳香下での脳活動を事象関連 電位 (event related potential: ERP) で観察することで, 精油 芳香がどのように感性と脳過程に働きかけているのか評価し た，その結果，行動およびERPで精油芳香による影響の可 能性が確認された

\section{2. 実 験 方 法}

本研究では集中力や記憶力を高めると想定される精油を アロマセラピストにブレンドしてもらった，試料は精油の中 でも集中力や記憶力と関連するとされている成分である, ローズマリー・シネオール 1,8 (抽出部位 $=$ 葉・枝）および レモン（抽出部位＝果皮）のブレンド精油である. ローズマ リーについては, ワーキングメモリのみならず長期記憶への
影響が大きく $[1] ，$ ローズマリーに含まれるシネオール 1,8 による影響であることが考えられる $[2]$ ，レモンについては ラット研究で副交感神経を司る前脳の内側部と腹側部の血流 が抑制されていることが判明している $[3]$ ，この事から交感 神経が優位となり体が活発な状態であると関連付けることが 出来る。また神保らの研究では, アルッハイマー病を含む認 知症患者へのアロマ芳香効果を検証した結果, アロマの芳香 をするとTDASスコア（タッチパネル式認知症評価方法の 点数）が有意に改善された [4]。 その際, 交感神経を活発化 する用途として芳香に用いたのが, ローズマリー・カンファー とレモンのブレンドである.

精油ブレンドの効果を評価する方法として, 本研究では, まずEFL (English as a foreign language：外国語としての英語) 授業における長期に渡る学習効果を評価した。学習効果を測 定するため, EOAE (essential oil aroma environment：精油 芳香環境）で授業したターゲット群と使わなかったコント ロール群について，授業内容についてのテスト成績を比較し たところ平均点に差があり（有意ではない），精油による成績 の向上の可能性が確認された，更に精油の学習効果のメカニ ズムを解明するため, オドボール課題による ERP 調査を実施 した。その結果, EOAEの影響と推定される脳波成分が観測 された，以下，その結果についてまとめる。

\section{1 行動調查}

調査対象は女性 74名（大学 $1 \sim 4$ 年生）の健常者である. 実施は研究趣旨や方法等について口頭で説明し，同意を得た 上で行われた。そのうちの51名はターゲット群として集中 
力や記憶力を高めるとされる精油のEOAEで実施し, 残る 23 名は香油芳香のない環境によるコントロール群とした。

\section{1 .1 実験プロトコール}

試料はジャスミンアロマティーク社 (Jasmin AROMATIQUE organics Co., Ltd.) で調合された, ローズマリー・シネオール1,8 (学名：Rosmarinusofficinalisct 1.8 cineole 原産地：Morocco 栽培方法: Organic 抽出方法: 水蒸気蒸留法) およびレモン (学名：Citrus limonum 原産地：Italy栽培方法：Organic 抽 出方法：圧搾法）を使用した。芳香はムエット（芳香紙） 30 本に対して $5 \mathrm{ml}$ の精油を漬し, 被験者一人に対して一本を学 習卓上に置くよう指示した。授業実施者拀よび授業内容はど ちらの群も同様であり，実施時間は18Hであった，授業で はFood and Culture of Britain [5] から選択した5 単元を扱 い，テストは単元で学習した内容に基づいて作成された。

\subsection{2 結 果}

ターゲット群のテスト平均が71.1 \pm 24.3 であったのに対 して, コントロール群のテスト平均は $66.4 \pm 24.8$ であった. 有意差があるとは言えないが, テスト平均はEOAEに学習 促進傾向が表れたものと解釈した，ただし，調查対象者の精 油㧍よび英語に対する日常的な接触, 調查当日の健康状態, 前日の睡眠時間等の調查が不足しているほか, 成績分布が幅 広いため, 効果の検証には追跡調査が必要である.

\subsection{ERP 調查}

行動調查においてEOAEの学習促進の傾向があったた め, その脳メカニズムを探る脳波計測実験を行った。集中力 や記憶力を高めるEOAEの効果を測るため, 注意レベルを 示唆するP 300 成分を観察する事を目標に, オドボール課題 による聴覚系の活動にかかわる脳波現象を観測した，調查対 象は, 健常な成人 11 名 (年齢 $21.9 \pm 1.5$ 歳, 女性 5 名, 男性 6名)である。調查実施にあたり, 玉川大学倫理委員会の承 認を得た。また，被験者には調査目標捛よび方法等について 書面ならびに口頭で説明して同意を得た。

\subsection{1 実験プロトコール}

試料は行動調査で使用されたものと同ロットのブレンド精 油である. 被験者は背もたれつきの椅子に座った状態で, 国 際10-20法に基づき, 頭皮上9か所 ( Fz, Pz, Cz, F3, C3, P3, F4, P4, C4）に活性生体電極を装着して基準電極は鼻とし た。脳波記録室は閉鎖された空間であるため, 芳香濃度は定 量化せず，被験者が主観的に心地よいと感じる精油付ムエッ トを5分間嗅いだ後に聴覚オドボール課題を行った。オド ボール課題とは識別可能な 2 種類の感覚刺激を用いた弁別反 応課題で, 低頻度刺激に対して陽性成分ピークを持つP300 が測定される。標準刺激として $1000 \mathrm{~Hz}$ (呈示確率 $80 \%$ ), 非標準刺激として $2000 \mathrm{~Hz}$ (呈示確率 20\%) のトーンパース トをランダムに呈示した。課題中は非標準刺激時のボタン押 しを教示した。

\subsection{2 結 果}

脳波解析は刺激提示 $100 \mathrm{~ms}$ 前から刺激提示後 $800 \mathrm{~ms}$ ま での区間を加算平均した結果, 被験者全員のERP結果 (図1, 図2), 拈よび個々のERP結果（図3, 図4）のいず れにも，芳香による影響と考えられる成分が確認された。 記録した中でも成分が大きく表出している Czに注目してみ ると，被験者全員の結果（図3）によれば，1）199msでp3a と推定される成分のピーク值がターゲットでは $4.1 \mu \mathrm{v}$, コントロールでは $5.2 \mu \mathrm{v}, 2) 127 \mathrm{~ms}$ で MMN と推定される 成分のピーク值がターゲットでは $2.5 \mu \mathrm{v}$ ，コントロールで は3.2 $\mu \mathrm{v}$ が確認出来た。更に芳香による影響と推定される ターゲット成分のピーク值が 3) $20 \mathrm{~ms} て ゙-1.3 \mu \mathrm{v}$ ，打よび 4) $370 \mathrm{~ms}$ で $3.2 \mu \mathrm{v}$ で確認された。

次に二人の被験者 A (図 3), B (図4)のデー夕を同じく $\mathrm{Cz}$ で細かく比較した結果, 個体差があることが明らかに なった。まず 1) p3a と推定される成分の潜時は被験者 $\mathrm{A}$ と Bで共に約200msで検出されているが，ピーク值はAでは ターゲットとコントロールの差異がないのに対して，Bで は夕ーゲット $8.6 \mathrm{~m} \mu \mathrm{v}$, コントロール $10.3 \mu \mathrm{v}$ と成分は大き
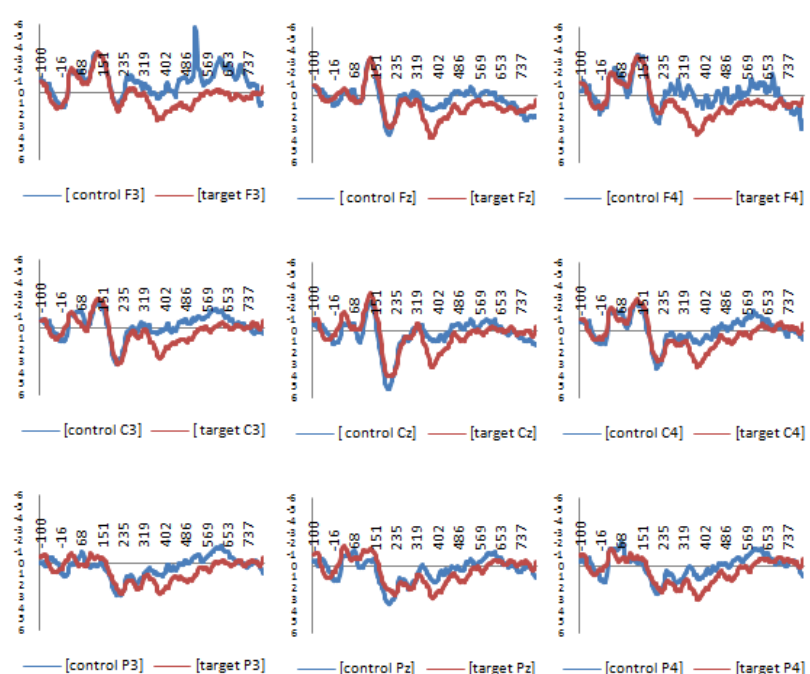

図1 ターゲット群 (芳香) およびコントロール群 (無芳香) の $\operatorname{ERP}(n=11)$

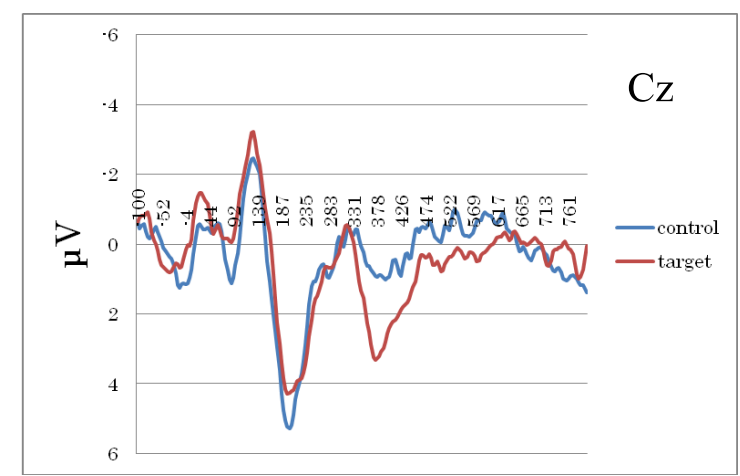

図2

2 ターゲット群 (芳香) およびコントロール群 (無芳香) の $\operatorname{ERP}(n=11)$ 




図3 被験者Aのターゲット刺激 (芳香) およびコントロール 刺激 (無芳香) に対するERP

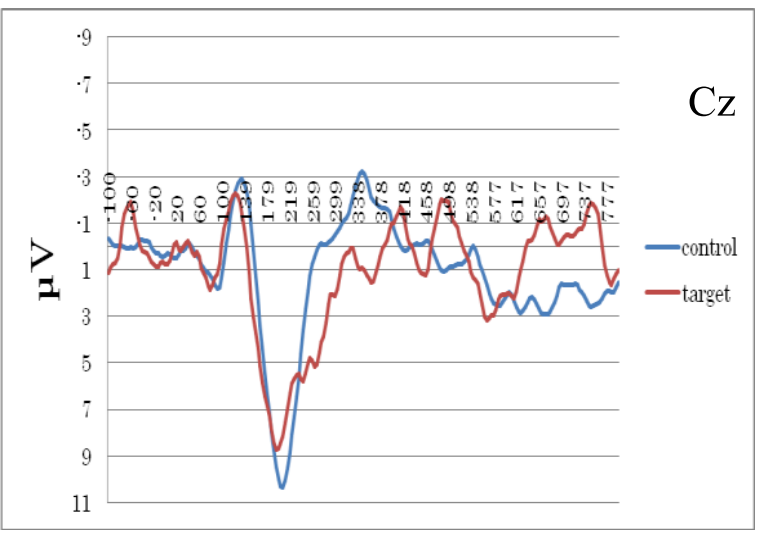

図4 被験者Bのターゲット刺激 (芳香) およびコントロール 刺激 (無芳香) に対するERP

く差異も確認出来た，次に2) MMNを示唆する成分の潜 時は被験者 $\mathrm{A}$ と Bで共に約 $130 \mathrm{~ms}$ で検出されているが,

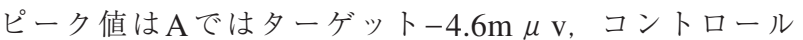
$-3.4 \mu \mathrm{v}$ と成分の差異が見られたのに対して，Bではター ゲットとコントロールの差異がなかった。ささらに更に図 1 では 3）20msと4）370msで明らかだった成分はAB共に表 出していない.

\section{3 アンケート調查}

日常生活の中には多様な香りが存在する。この香りによっ て, 人々は様々な影響を受けていることが想定されるが, 感性の在り方によって脳活動は変化するのであろうか.ささら に, 香りに対しての知識や経験によって, 脳活動への影響は 考えられるのであろうか. 例えば，焼き肉の香りは食欲をそ そる事が多いと考えられるが, 味覚知識のない場合でも食欲 をそそる香りであるのか.

そこで，嗅覚感性と脳活動への関連性を調査するため, 被験者 11 名に, 日常生活における嗅覚の感性およびEOAE ブレンド精油についての主観評価五件法アンケートを調査 した.
まず73\%が普段の生活で匂いに対して敏感で, 食べ物 $(73 \%)$, 洗濯物 $(55 \%)$, 洗髪料 $(46 \%)$, 洗剂と香水 $(36 \%)$, の順に関心があると回答した。また， $82 \%$ が用品の香り を意識していた。つまり，嗅覚的な認知は日常生活の中で常 に行われていると考えられる。 また, ブレンド精油に対して 91\%が香りを好み，36\%はとりわけ好感を持っていた。 さらに，芳香による効果については $46 \%$ が覚醒感を感じた のに対して，18\%は感じていない，EAOE課題実施におけ る疲労感を感じる被験者はおらず，改めて嗅ぎたい香りであ ると $82 \%$ が回答した。 ブレンドされた精油成分について, レモンおよび柑橘系という回答はあったが，成分そのものに ついての知識は少ないようである.

アンケート結果から, 被験者の多くが香りに対しての意識 が高いと想定されるが，ブレンド精油についての知識はない ことが明らかになった。また，本研究では集中力や記憶力を 高めると想定される精油をアロマセラピストにブレンドして もらったが，その旨は被験者に知らせていない。そそれにも拘 わらず，被験者のほとんどが香りを好み，半数近くが精油に よって覚醒度があがったと感じている。この事から，精油芳 香は受け手次第で効果があることが示唆される。

\section{3. 考察}

本研究では行動調査および脳波計測に基づいて精油芳香 の認知過程について検討した。まずは集中力や記憶力と関 連するとされている芳香環境で, 学習という典型的な認知 過程の効果を行動調査で検証したところ，芳香効果が確実 にあるという結果は得られなかった。次に脳波による検証 を行ったところ，EOAEの影響を示唆する成分が4つ確認 されたが，その成分が意味するところは明らかではない．

これらの結果から，精油芳香は脳に何らかの影響を与える ことは確実と考えられる。しかし，EOAEによって覚醒水 準があがったのか，あるいは集中力，思考力，記憶力など何 等かの学習に関連する機能が向上しているかを判断するには 材料が足りない.

一方で，被験者の個々人の何らかの要因によるものか ERPの個体差が大きかった事から，精油芳香が効果をおよ ぼす認知過程には個体差があることが示唆される。また, その効果は精油芳香に対する慣れ親しみによって変化する 可能性がある，さらに，本研究では集中力や記憶力を高め る効用があるとされる精油を使用したが，リラックス効果 など他の効用が詔われる精油の場合には，どのような効果 が見られるかは明らかではない。精油の種類による差異も また検証する必要がある。

技術的には，精油芳香の濃度・吸入量の定量性，さらには 香水のような精油を含む芳香を日常的に使っている場合や各 被験者の健康状態のコントロールなども課題である. 


\section{4. おわりに}

古来, 精油芳香は芳香植物由来の精油を使った補完代替 医療に使われてきた。しかし現状では，医学領域において その効果はいまだ科学的には検証されていない，本研究で は，精油芳香の学習に対する効果および精油芳香にともなう 脳現象を明らかにすることを目標に行動調査および脳波計測 による解析を行った。 その結果, 認知過程のメカニズムは明 らかではないが，精油芳香による影響が脳波に確認された。 現状では行動実験も㛜密とはいえず，脳波計測実験もまた不 十分なもので, 確実に言えることは少ない. 今後は, より厳 密な実験で精油の学習への効果を明らかにしていきたい.

\section{参 考 文 献}

[1] Moss, M., Cook, J., Wesnes, K. and Duckett, P.: Aromas of rosemary and lavender essential oils differentially affect cognition and mood in healthy adults, Int J Neurosci, 113, pp.15-38, 2003.

[2] Moss, M., Oliver, L.: Plasma 1,8-cineple correlates with cognitive performance following exposure to rosemary essential oil aroma, Therapeutic Advances in Psychopharmacology, SAGEDOI, 10.1177/2045125312436573, 2012.
[3] Shioda, S. : 香りはなぜ脳に効くのかアロマセラピーと先 端医療, NHK publication, ISBN: 9784140883853, 2012.

[4] Jimbo, D., Kimura, Y., Taniguchi, M., Inoue, M., Uramaki, K.: Effect of aromatherapy on patients with Alzheimer's disease, Psychogeriatrics, 9(4), pp.173-179, 2009.

[5] Wallace, G. : Food and Culture of Britain, 松柏社, 2001.



\section{上條＼cjkstart美和子（正会員）}

Surrey University 言語学修士, 玉川大学文学 修士を持ち 2013 年には玉川大学脳情報研究 科満期退学する。2010年 相模女子大学学芸 学部メディア情報学科講師を経て, 2013 年 より同大学英語文化コミュニケーション学科 講師となる，外国語としての英語教育および言語, 学習と知識 に関わる脳活動に関心を持つ。

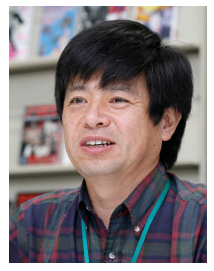

大森 隆司 (非会員)

1980年 東京大学工学修了, 1987年 東京農工 大学工学部講師を経て 1988年より同助教授, 1998 年より教授, 2000 年 5 月より北海道大学 大学院工学研究科教授を経て，2006 年 4 月よ り玉川大学教授, 現在にいたる. 博士 (工学). 脳という神経機構に知能が生まれる情報的メカニズムに興味が あり，心に関わる脳の情報処理過程の解明を試みている。 